\title{
GROWTH, PHYSIOLOGY AND YIELD OF FORMOSA 'PAPAYA' CULTIVATED UNDER DIFFERENT DOSES OF COATED AND CONVENTIONAL UREA ${ }^{1}$
}

\author{
GABRIEL BARBOSA DA SILVA JÚNIOR ${ }^{2 *}$, ÍTALO HERBERT LUCENA CAVALCANTE ${ }^{3}$, EDUARDO MONTEIRO \\ SANTOS $^{4}$, FRANCISCA GISLENE ALBANO ${ }^{4}$, ADRIEL MOURA SILVA $^{5}$
}

\begin{abstract}
Mineral fertilizer management is one of the most important agronomic techniques applied in papaya cultivation, which generally extracts large amounts of nutrients from soil, especially nitrogen. This study aimed to assess the phytotechnical and physiological attributes and yield of 'Formosa' papaya hybrid Caliman 01 as a function of different doses of coated and conventional urea in the region of Bom Jesus - PI, Brazil. The treatments were arranged in a factorial scheme $(2 \times 4)$ and distributed in a randomized block design with four replications, corresponding to 2 nitrogen sources (coated urea, $43 \%$ of $\mathrm{N}$; and conventional urea, $45 \%$ of $\mathrm{N}$ ) and 4 doses nitrogen (350, 440, 530 and 620 g per plant). The $\mathrm{N}$ doses used corresponded to 80, 100, 120 and $140 \%$ of the nitrogen fertilization. It was used six plants per plot with two row borders, totaling 192 plants cultivated in the field. It was assessed the intercepted photosynthetically active radiation (int.PAR), radiation interception efficiency (PAREff.), leaf area index (LAI), plant height, stem diameter and yield. The coated urea promotes a higher growth and yield of 'Formosa' papaya compared to the conventional urea. The application of $1.0 \mathrm{~g}$ of coated $\mathrm{N}$ promotes the production of $2.87 \mathrm{~g}$ of fruit per hectare while the application of $1.0 \mathrm{~g}$ of conventional $\mathrm{N}$ produces only $1.89 \mathrm{~g}$ of fruit per hectare, showing that the source of polymerized $\mathrm{N}$ increases the use efficiency of $\mathrm{N}$ applied to soil.
\end{abstract}

Keywords: Carica papaya. Coated N. Fruticulture. Fruit production.

\section{CRESCIMENTO, FISIOLOGIA E PRODUTIVIDADE DO MAMOEIRO FORMOSA CULTIVADO SOB DIFERENTES DOSES DE UREIA PROTEGIDA E CONVENCIONAL}

RESUMO - O manejo da adubação mineral é uma das mais importantes técnicas agronômicas aplicadas no cultivo do mamoeiro, que de modo geral, extrai grandes quantidades de nutrientes no solo, com destaque para o nitrogênio. Objetivou-se avaliar os atributos fitotécnicos, fisiológicos e a produtividade do mamoeiro Formosa híbrido Caliman 01 em função de diferentes doses de ureia protegida e convencional na região de Bom JesusPI. Os tratamentos foram dispostos em esquema fatorial $(2 \mathrm{x} 4)$, distribuídos em blocos ao acaso, com 4 repetições, correspondentes a 2 fontes de nitrogênio (ureia protegida, $43 \%$ de N; e ureia convencional, $45 \%$ de N) e 4 doses de nitrogênio (350, 440, 530 e 620 g planta $^{-1}$ de N). As doses de $\mathrm{N}$ utilizadas são correspondentes às percentagens de $80,100,120$ e $140 \%$ da adubação nitrogenada. Utilizou-se 6 plantas por parcela, sendo duas bordaduras, totalizando 192 plantas cultivadas no campo. Avaliou-se a radiação fotossinteticamente ativa interceptada (RFAint.), eficiência de interceptação da radiação (Ef.RFA), índice de área foliar (IAF), altura de planta, diâmetro do caule e produtividade. A ureia protegida promove maior crescimento e produtividade do mamoeiro formosa em relação à ureia convencional. A aplicação de $1,0 \mathrm{~g}$ de $\mathrm{N}$ protegido promove a produção de 2,87 $\mathrm{g}$ de frutos por hectare enquanto que a aplicação de $1,0 \mathrm{~g}$ de $\mathrm{N}$ na fonte ureia convencional produz apenas $1,89 \mathrm{~g}$ de frutos por hectare, mostrando que a fonte de $\mathrm{N}$ polimerizada incrementa a eficiência de uso do $\mathrm{N}$ aplicado no solo.

Palavras-chave: Carica papaya. N-protegido. Fruticultura. Produção de frutos.

\footnotetext{
*Corresponding author

${ }^{1}$ Received for publication in .07/07/2014; accepted in $02 / 22 / 2016$.

Paper extracted from the master thesis of the first author.

${ }^{2}$ Department of Plant Science, Research Center of Agricultural Sciences, Campus Ministro Petrônio Portella, Universidade Federal do Piauí, Teresina, PI, Brazil. gabrielbarbosa@ufpi.edu.br.

${ }^{3}$ Campus of Agricultural Sciences, Universidade Federal do Vale do São Francisco, Petrolina, PE, Brazil. italo.cavalcante@univasf.edu.br.

${ }^{4}$ Doctoral student in Soils and Plant Nutrition, Campus of Pici, Universidade Federal do Ceará, Fortaleza, CE, Brazil eduardomonteirosant@yahoo.com.br; gislene.fga@gmail.com.

${ }^{5}$ Graduation student in agronomy, Campus Prof. Cinobelina Elvas, Universidade Federal do Piauí, Bom Jesus, PI, Brazil. adriel-moura@hotmail.com.
} 


\section{INTRODUCTION}

Papaya (Carica papaya L.) is an herbaceous plant, typically found in tropical areas, with fast and frequent production throughout the year. Brazil is the world's largest producer of papaya, with an average yield of $52.19 \mathrm{t} \mathrm{ha}^{-1}$, especially in Bahia and Espírito Santo, the main Brazilian producing states (IBGE, 2012).

Mineral fertilizer management is one of the most important agronomic techniques applied in papaya cultivation, which generally extracts large amounts of nutrients from soil, especially nitrogen, which is the nutrient required in larger quantities throughout the crop cycle (MARINHO et al., 2010). Traditionally, it is used different $\mathrm{N}$ sources for papaya nitrogen fertilization, such as ammonium nitrate, ammonium sulfate, and most commonly, the urea, as observed in studies developed by Santos et al. (2014) and Santos et al. (2016). However, these soluble $\mathrm{N}$ forms are more susceptible to losses to the environment through ammonia volatilization and nitrate leaching (NOELLSCH et al., 2009).

In order to reduce losses occurred during the conventional nitrogen fertilizer practice, it has sought technological alternatives that can increase the nitrogen fertilization efficiency. Among the feasible means, it has studied the use of nitrogen fertilizers of controlled release, which constitute inputs whose granules are protected with a layer composed of mineral additives and polymers, favoring gradually the nitrogen supply in the soil solution and, consequently, improving its use efficiency by plants throughout the cultivation (GRANT et al., 2012).

In this sense, nitrogen fertilization effect of slow release, in economically important crops, has been reported in the scientific literature with emphasis on studies conducted with major crops, such as wheat (GRANT et al., 2012) and corn (NOELLSCH et al., 2009), besides vegetable crops such as tomato (FAN et al., 2009) and cabbage (RODRIGUES et al., 2010), and fruit species such as peach (KANDIL et al., 2010), guava (OSMAN et al., 2009) and mango (EMAN et al., 2009), summarizing its positive effects on their phytotechnical and productive attributes. However, specifically for papaya cultivation, studies on the feasibility of using controlled release fertilizers in Brazil and in the world are still incipient.

Given the above, this study aimed to assess the phytotechnical and physiological attributes and yield of 'Formosa' papaya hybrid Caliman 01 as a function of different doses of coated and conventional urea in the region of Bom Jesus - PI, Brazil.

\section{MATERIAL AND METHODS}

The experiment was conducted during the period from November 30, 2011 to February 15, 2013 at the fruticulture experimental farm of the Campus Professor Cinobelina Elvas (CPCE), at the Universidade Federal do Piaui (UFPI), located in Bom Jesus - PI, Brazil. The area is located at geographical coordinates $09^{\circ} 04^{\prime} 28^{\prime \prime} \mathrm{S}$ and $44^{\circ} 21^{\prime}$ $31^{\prime} \mathrm{W}$, with an average altitude of $277 \mathrm{~m}$ during the period of November 30, 2011 to February 15, 2013. Bom Jesus is located in the semiarid region of Piauí state with warm and humid climate, classified by Koppen as Cwa type.

For the seedlings production, it was used certified seeds of 'Formosa' papaya hybrid Caliman 01 provided by the Instituto Capixaba de Pesquisa, Assistência Técnica e Extensão Rural (INCAPER) of the Espírito Santo State. It was used a substrate composed of sandy soil and cattle manure in the proportion $3: 1$, respectively, adding $1.4 \mathrm{~kg}$ of single superphosphate $\left(18 \%\right.$ of $\left.\mathrm{P}_{2} \mathrm{O}_{5}\right)$ and $1.0 \mathrm{~kg}$ potassium chloride $\left(60 \%\right.$ of $\left.\mathrm{K}_{2} \mathrm{O}\right)$ per $\mathrm{m}^{3}$ of substrate. Seedlings were cultivated under protected conditions (screen with $50 \%$ shading $)$ in polyethylene bags $(23 \times 12$ $\mathrm{cm})$ filled with substrate. It was sown three seeds per bag, with the thinning carried out 15 days after plant emergence and being left only the most vigorous per container; the seedlings were transferred to the field as they had approximately $20 \mathrm{~cm}$ high, 60 days after sowing (MARIN, 2004).

The treatments were arranged in a factorial scheme $2 \times 4$, corresponding to 2 nitrogen sources (the coated urea Kimcoat $\mathrm{N}^{\circledR}$, coated with polymer layers, and conventional urea) and 4 nitrogen levels (350, 440, 530 and 620 g per plant). The treatments were distributed in a randomized block design with 4 replications and 6 hermaphrodite plants of 'Formosa' papaya per plot, being 4 useful plants and 2 row borders, cultivated at double spacing $(3.8 \mathrm{~m}$ between double rows $\times 1.8 \mathrm{~m}$ between rows $\times 2.0 \mathrm{~m}$ between plants), totaling 192 plants with a density of 1,785 plants ha ${ }^{-1}$.

The $\mathrm{N}$ doses used corresponded to 80,100 , 120 and $140 \%$ of nitrogen fertilization, as recommended by Costa and Costa (2003). The nutrient amounts (g plant ${ }^{-1}$ ) were applied monthly in top dressing following recommendations of Costa and Costa (2003), which are presented in Table 1. 
G. B. SILVA JÚNIOR et al.

Table 1. Nutrient amounts applied monthly, in top dressing, for papaya cultivation.

\begin{tabular}{|c|c|c|c|c|c|c|c|}
\hline \multirow{2}{*}{$\begin{array}{c}\text { Time of } \\
\text { application }\end{array}$} & \multicolumn{5}{|c|}{$\mathrm{N}$} & \multirow{2}{*}{$\mathrm{K}_{2} \mathrm{O}$} & \multirow{2}{*}{$\mathrm{P}_{2} \mathrm{O}_{5}$} \\
\hline & $\begin{array}{c}\text { Recommended } \\
\text { dose* }\end{array}$ & $80 \%$ & $100 \%$ & $120 \%$ & $140 \%$ & & \\
\hline Mar./12 & 25 & 20 & 25 & 30 & 35 & 5 & - \\
\hline Apr./12 & 25 & 20 & 25 & 30 & 35 & 10 & - \\
\hline May/12 & 35 & 28 & 35 & 42 & 49 & 60 & 40 \\
\hline June/12 & 35 & 28 & 35 & 42 & 49 & 20 & - \\
\hline July/12 & 35 & 28 & 35 & 42 & 49 & 30 & - \\
\hline Aug./12 & 40 & 32 & 40 & 48 & 56 & 40 & 25 \\
\hline Sept./12 & 40 & 32 & 40 & 48 & 56 & 40 & - \\
\hline Oct./12 & 50 & 40 & 50 & 60 & 70 & 40 & - \\
\hline Nov./12 & 50 & 40 & 50 & 60 & 70 & 40 & 25 \\
\hline Dec./12 & 35 & 28 & 35 & 42 & 49 & 40 & - \\
\hline Jan./13 & 35 & 28 & 35 & 42 & 49 & 35 & - \\
\hline Feb./13 & 35 & 28 & 35 & 42 & 49 & 35 & - \\
\hline Total & 440 & 350 & 440 & 530 & 620 & 395 & 90 \\
\hline
\end{tabular}

*Splitting of N doses according to Costa and Costa (2003), according to rates of each treatment.

The conventional urea contained $45 \%$ of $\mathrm{N}$, whereas the coated urea presented $43 \%$ of $\mathrm{N}$. Thus, the doses 350, 440, 530 and $620 \mathrm{~g}$ per plant corresponds, approximately, to the amounts of 780 , 980, 1180, $1380 \mathrm{~g} \mathrm{plant}^{-1}$ of conventional urea and $815,1,025,1,230$ and $1,440 \mathrm{~g} \mathrm{plant}^{-1}$ of coated urea, throughout the cultivation period.

Potassium chloride $\left(60 \%\right.$ of $\left.\mathrm{K}_{2} \mathrm{O}\right)$ was used as potassium source and phosphorus fertilization was performed with single superphosphate $(18 \%$ of $\mathrm{P}_{2} \mathrm{O}_{5}$ ). All fertilizers (urea, single superphosphate and potassium chloride) were applied in a circular circle under the canopy projection, $20 \mathrm{~cm}$ from the stem and slightly incorporated into the soil with the assistance of field hoes. All fertilizations were finished in February 2013, corresponding to the last harvest month.

The soil of the experimental area is classified as a Quartzarenic Neosol (Entisol) (EMBRAPA, 2013) with sandy texture. The physical and chemical characteristics at depths from 0.0 to 0.20 and from 0.20 to $0.40 \mathrm{~m}$, before experiment installation, are summarized in Table 2, following method described by Raij et al. (1987).

Table 2. Soil physical and chemical characteristics in the experimental area $(0.0-0.20$ and $0.20-0.40 \mathrm{~m})$.

\begin{tabular}{lccc}
\hline \multicolumn{1}{c}{ Soil characteristic } & Unit & $0-20$ & Depth $(\mathrm{cm})$ \\
\cline { 3 - 4 } & & 5.0 & $20-40$ \\
\hline $\mathrm{pH}-\mathrm{H}_{2} \mathrm{O}(1: 2.5)$ & - & 0.23 & 0.8 \\
Potassium & $\mathrm{cmol}_{\mathrm{c}} \mathrm{dm}^{-3}$ & 1.6 & 0.11 \\
Calcium & $\mathrm{cmol}_{\mathrm{c}} \mathrm{dm}^{-3}$ & 0.4 & 0.2 \\
Magnesium & $\mathrm{cmol}_{\mathrm{c}} \mathrm{dm}^{-3}$ & 0.02 & 0.02 \\
Sodium & $\mathrm{cmol}_{\mathrm{c}} \mathrm{dm}^{-3}$ & 0.0 & 0.0 \\
Aluminum & $\mathrm{cmol}_{\mathrm{c}} \mathrm{dm}^{-3}$ & 1.7 & 1.3 \\
Hydrogen & $\mathrm{cmol}_{\mathrm{c}} \mathrm{dm}^{-3}$ & 3.9 & 2.5 \\
CEC & $\mathrm{cmol}_{\mathrm{c}} \mathrm{dm}^{-3}$ & & \\
\hline
\end{tabular}

${ }^{*} \mathrm{CEC}$ : Cation Exchange Capacity. 
Table 2. Continuation.

\begin{tabular}{|c|c|c|c|}
\hline \multirow{2}{*}{ Soil characteristic } & \multirow{2}{*}{ Unit } & \multicolumn{2}{|c|}{ Depth (cm) } \\
\hline & & $0-20$ & $20-40$ \\
\hline P (Mehlich-1) & $\mathrm{mg} \mathrm{dm}{ }^{-3}$ & 18.0 & 14.0 \\
\hline Organic matter & $\%$ & 1.0 & 0.4 \\
\hline Base saturation & $\%$ & 57.0 & 48.0 \\
\hline Clay & $\mathrm{g} \mathrm{kg}^{-1}$ & 60 & 60 \\
\hline Silt & $\mathrm{g} \mathrm{kg}^{-1}$ & 20 & 20 \\
\hline Sand & $\mathrm{g} \mathrm{kg}^{-1}$ & 920 & 920 \\
\hline
\end{tabular}

${ }^{*}$ CEC: Cation Exchange Capacity.

The data related to climatic variables (air temperature, relative air humidity and rain precipitation), collected at the meteorological station of the UFPI/CPCE during the experiment conducting, are shown in Figure 1.
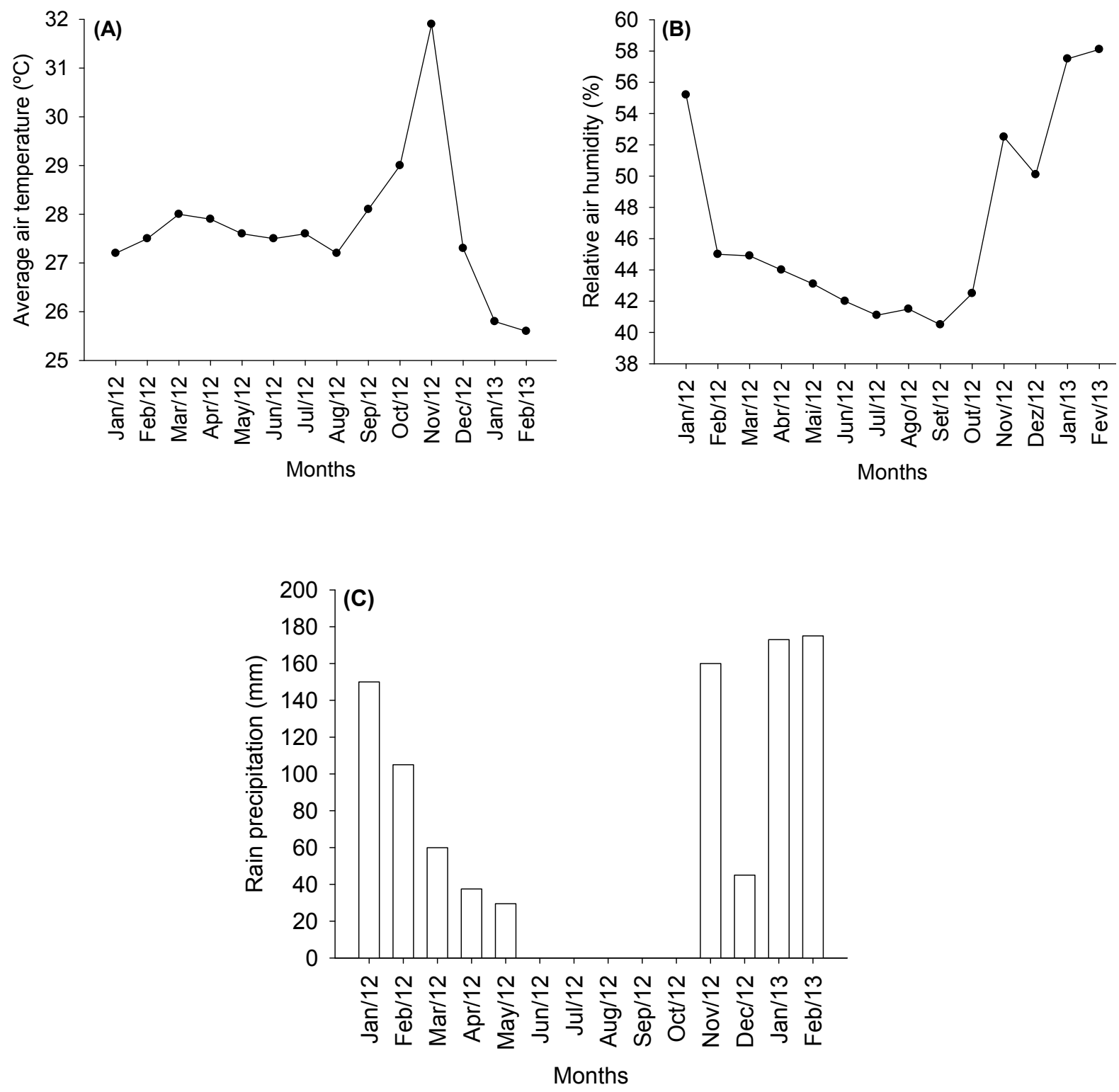

Figure 1. Air temperature (A), relative air humidity (B) and rain precipitation (C) while performing the experiment. 
Soil tillage was conducted 60 days before transplanting the seedlings and liming was carried out according to soil chemical analysis results for the experimental area. It was applied $1.22 \mathrm{t} \mathrm{ha}^{-1}$ of dolomitic limestone $(\mathrm{RNV}=75 \%)$ in total area, increasing base saturation to $80 \%$ (MARIN, 2004). Half dose was applied before plowing and the other half after plowing and before harrowing by using a harrow and thereby ensuring greater application uniformity. The pits were opened with dimensions of $40 \times 40 \times 40 \mathrm{~cm}$, in which were added $170 \mathrm{~g}$ of single superphosphate $\left(18 \%\right.$ of $\left.\mathrm{P}_{2} \mathrm{O}_{5}\right)$, following the recommendations of Costa and Costa (2003).

Seedlings transplantation was conducted on February 9, 2012 using two plants per pit spaced 20 $\mathrm{cm}$ from each other, being trained with wooden stakes $1.0 \mathrm{~m}$ long. Thinning was carried out at the 120 days after flowering, based on the plants sexing, leaving only one hermaphrodite plant per pit (MARIN, 2004).

The irrigation was performed by drip system, providing a daily average water depth of $6.9 \mathrm{~mm}$, equivalent to the daily evaporation obtained based on the class A evaporation pan method installed at the meteorological station of the UFPI/CPCE and corrected according with the crop coefficient $(\mathrm{Kc})$ of papaya, as in Coelho Filho et al. (2006).

Weed control was carried out monthly in the inter-row by hoeing and mowing, and pests and diseases control was conducted according to the recommendations for papaya commercial production systems (OLIVEIRA et al., 1995).

At 120 days after transplanting, when the plants were in full bloom, the following physiological variables were estimated: a) intercepted photosynthetically active radiation

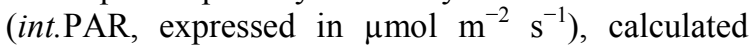
following the recommendations of Varlet-Grancher et al. (1989), as follows: PAR = inc. PAR $-t s . \mathrm{PAR}$, where inc.PAR is the incident radiation and $t s$. PAR is the transmitted radiation to soil, highlighting that both radiation (inc.PAR and $t$ s.PAR) was determined in triplicate, in a sunny day between 9:00 and 11:00 $\mathrm{h}$ and at the same time using a ceptometer (Decagon Devices Inc., USA) with sensors installed below and above the canopy, respectively; b) PAR interception efficiency (PAREff.) by the crop, estimated by the ratio between int.PAR and inc.PAR.

At 275 days after transplanting, it was carried out the following assessments: a) plant height $(\mathrm{cm})$, using millimeter measuring tape $(0.01 \mathrm{~cm})$ and by measuring the distance from the base to the last leaf insertion; and b) stem diameter ( $\mathrm{mm})$, determined with a digital caliper $\left(0.01-300 \mathrm{~mm}\right.$, Digimess $\left.{ }^{\circledR}\right)$ measured at $20 \mathrm{~cm}$ from soil.

At harvest time, conducted from October 15, 2012 to February 15, 2013, totaling 120 days, it was determined the yield $\left(\mathrm{t} \mathrm{ha}^{-1}\right)$ considering the fruits harvested in all plants of the experimental plots (usable area of 4 plants per plot). Fruits were harvested weekly in the maturation stages 3 , when presented only 25 to $50 \%$ of the peel surface with yellowish color, according to the recommendations of Marin (2004). Thereafter, the fruits were selected, counted and weighed on a precision balance $(0.01 \mathrm{~g})$ in order to determine the fruit mass per plant and estimate the total yield given by the sum of fruit mass per plant throughout the harvest period for each treatment multiplied by the number of plants per hectare (1785 plants).

The results were submitted to analysis of variance for the diagnosis of significant effects between the sources and doses of nitrogen, using the $\mathrm{F}$ and Tukey's tests in order to compare the means of nitrogen sources. For $\mathrm{N}$ doses, it was applied the simple regression analysis using the statistical programs Assistat and SigmaPlot.

\section{RESULTS AND DISCUSSION}

By means of the analysis of variance of the phytotechnical and physiological attributes and yield of 'Formosa' papaya was found individual effect of sources and doses of nitrogen for plant height $(p<0.01)$, intercepted photosynthetically active radiation $(p<0.05)$, use efficiency of PAR $(p<0.05)$ and yield $(p<0.01)$. For the interaction between sources and the nitrogen fertilization doses studied, there was a significant effect on plant height $(\mathrm{PH})$, stem diameter (SD), intercepted photosynthetically active radiation (int.PAR), use efficiency of PAR (PAREff.) and yield (Pt) at 5\% probability (Table 3 ).

The interaction between different doses of nitrogen fertilization showed quadratic behavior for plant height, with estimated maximum values of 192.76 and $167.21 \mathrm{~cm}$ for doses of 466.08 and $510.21 \mathrm{~g}$ per plant, for the nitrogen sources coated (Figure 2A) and conventional (Figure 2B) urea, respectively. The maximum values found for the plants cultivated with coated urea $(192.76 \mathrm{~cm})$ are low compared to those found by Souza et al. (2005) $(240.0 \mathrm{~cm})$, who studied the growth and yield of 'Formosa' papaya fertirrigated with phosphorus by surface and subsurface drip in Cruz das Almas, BA, Brazil. This fact may be associated with the regional climatic conditions where the experiment was conducted, characterized by high temperature and low relative air humidity throughout the crop cycle (Figure 1), affecting papaya growth. On the other hand, the plant height values are higher than 180.0 $\mathrm{cm}$ as reported by Souza et al. (2007), who assessed papaya growth and yield under different nitrogen sources combinations. 
Table 3. Summary of analysis of variance related to measuring in plant height (PH), stem diameter (SD), intercepted photosynthetically active radiation (int.PAR), use efficiency of PAR (PAREff.), leaf area index (LAI) and yield (Pt) of 'Formosa' papaya cultivated under different doses of coated and conventional urea.

\begin{tabular}{|c|c|c|c|c|c|c|}
\hline \multirow[b]{2}{*}{ Source of variation } & $\mathrm{PH}$ & SD & int.PAR & PAREff. & LAI & $\mathrm{Pt}$ \\
\hline & $\mathrm{cm}$ & $\mathrm{mm}$ & $\mu \mathrm{mol} \mathrm{m} \mathrm{m}^{-2} \mathrm{~s}^{-1}$ & index & index & $\mathrm{tha}^{-1}$ \\
\hline $\mathrm{N}$ source $(\mathrm{F})$ & $76.14 * *$ & $1.62^{\mathrm{ns}}$ & $4.59 *$ & $4.62 *$ & $0.63^{\mathrm{ns}}$ & $25.49 * *$ \\
\hline Coated urea & $177.95 a$ & $65.76 \mathrm{a}$ & $962.44 b$ & $0.51 b$ & $0.24 \mathrm{a}$ & $10.89 \mathrm{a}$ \\
\hline Conventional urea & $158.86 b$ & $62.80 \mathrm{a}$ & $1228.87 \mathrm{a}$ & $0.65 \mathrm{a}$ & $0.24 \mathrm{a}$ & $6.91 b$ \\
\hline LSD & 4.55 & 4.71 & 258.63 & 0.13 & 0.06 & 1.62 \\
\hline $\mathrm{N}$ doses $(\mathrm{N})$ & $26.49^{* *}$ & $0.69^{\mathrm{ns}}$ & $2.99^{*}$ & $3.03^{*}$ & $0.74^{\mathrm{ns}}$ & $9.44 * *$ \\
\hline Interaction $(F \times D)$ & $8.77 *$ & $0.07 *$ & $4.46^{*}$ & $4.54^{*}$ & $0.31^{\mathrm{ns}}$ & $4.49^{*}$ \\
\hline CV $(\%)$ & 3.67 & 9.96 & 32.10 & 31.96 & 3.72 & 24.80 \\
\hline
\end{tabular}

$\mathrm{CV}=$ coefficient of variation; LSD = least significant difference; ${ }^{* *}=$ significant at $1 \%$ probability $(p<0.01) ;{ }^{*}=$ significant at $5 \%$ probability $(p<0.05)$; means followed by different letters in columns are statistically different by the Tukey's test at $5 \%$ probability.

Coated urea
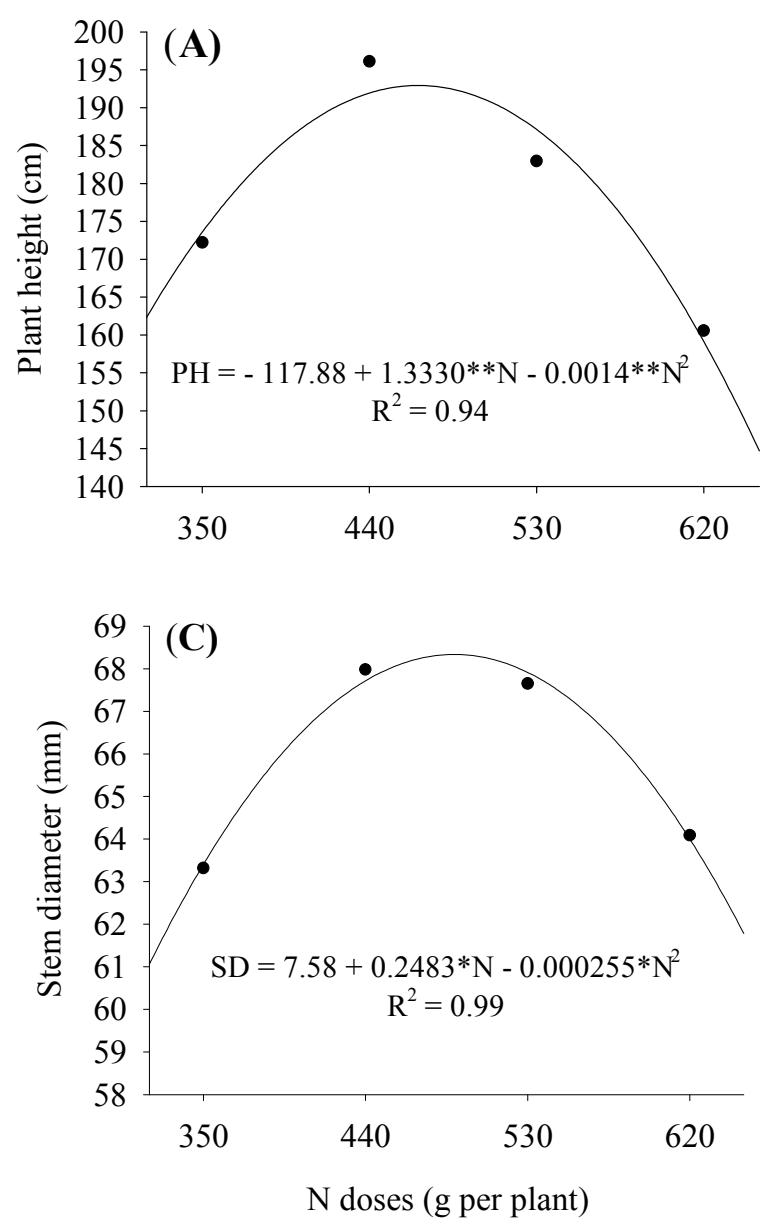

Conventional urea
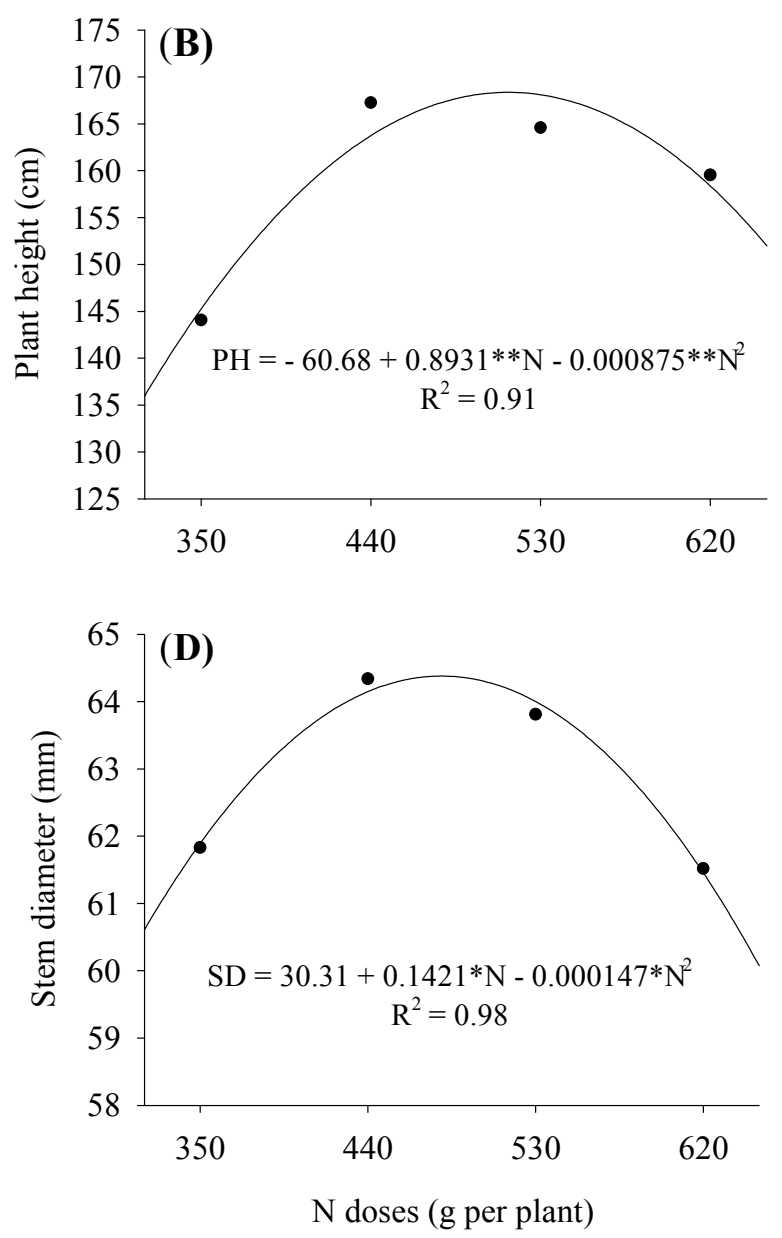

Figure 2. Height (A and B) and stem diameter (C and D) of 'Formosa' papaya plants cultivated under different doses of coated and conventional urea.

The low values reported by Souza et al. (2007) in relation to this study may be related to the planting spacing and population density, as reported by Resende and Costa (2003), who observed that planting density is a factor to be taken into account since plant population pressures affect markedly 
their growth and development. Thus, when there is an increase in the number of plants per unit area, there is also an increase in competition for essential growth factors such as light, nutrients and water. However, Souza et al. (2007) worked with single spacing and lower population density, whereas in this experiment was used double spacing with high population density.

Regarding the stem diameter, the maximum dose estimated of coated urea was $482.86 \mathrm{~g}$ per plant for a stem diameter of $68.02 \mathrm{~mm}$ (Figure 2C), whereas the conventional urea promoted a stem diameter of $64.65 \mathrm{~mm}$, which corresponds to the estimated dose of 488.33 g per plant (Figure 2D).

Compared to the estimated maximum doses, the coated urea was superior to the conventional urea at $15.28 \%$ for plant height by reducing its dose from 510.21 to $466.08 \mathrm{~g}$ per plant, which corresponds to a reduction of $9.46 \%$ or $44.13 \mathrm{~g}$ per plant applied to soil. With the same tendency, but in smaller proportions, it was also observed lower $\mathrm{N}$ doses for a higher value of stem diameter, with an increase of $5.21 \%$ in the diameter, which corresponds to a reduction of $5.47 \mathrm{~g}$ per plant when coated urea was used compared to conventional urea.

The superiority of the coated fertilizer for plant height and stem diameter is given by a better nitrogen availability applied under this source, which is involved directly in plant growth (TAIZ; ZEIGER, 2009) for a longer period in the soil, providing papaya plants larger sized.

The use of slow-release fertilizer was sufficient to increase the development of papaya plants, being possible to reduce the amount of $\mathrm{N}$ applied in soil and hence the environmental pollution through nitrates leaching $\left(\mathrm{N}-\mathrm{NO}_{3}^{-}\right)$, as reports Kandil et al. (2010) when verifying similar results in studies with slow-release fertilizers on growth, nutrition and production of peach in Egypt.

In relation to the physiological variables, for the interaction between sources and doses of nitrogen fertilization, int.PAR presented estimated maximum values of $1,296.50$ and $1,578.70 \mu \mathrm{mol} \mathrm{m} \mathrm{m}^{-2}$ $\mathrm{s}^{-1}$ in doses of 494.85 and $461.65 \mathrm{~g}$ per plant for the sources coated (Figure 3A) and conventional (Figure 3B ) urea, respectively.

For PAREff., the maximum dose estimated to nitrogen fertilization with coated urea was $494.41 \mathrm{~g}$ per plant, which correspond to 0.665 (Figure 3C), whereas conventional urea promoted an index of 0.796 related to the dose estimated of $457.94 \mathrm{~g}$ per plant (Figure 3D).
Coated urea
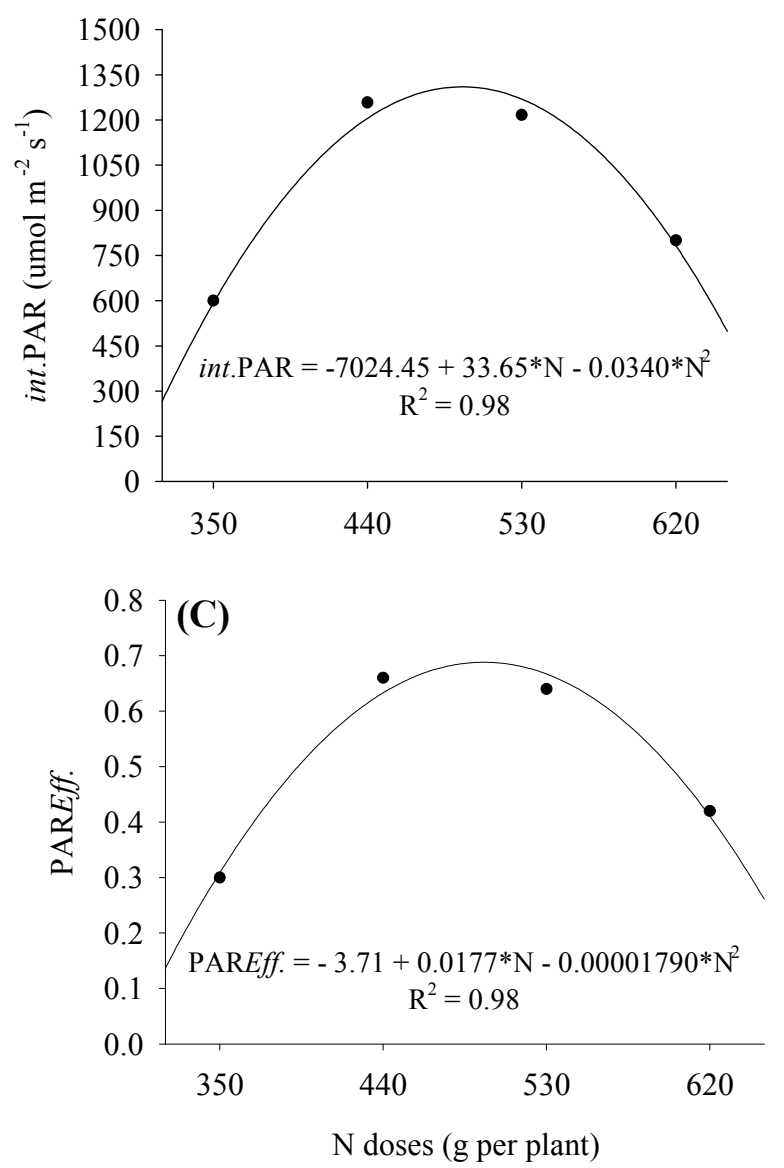

Conventional urea
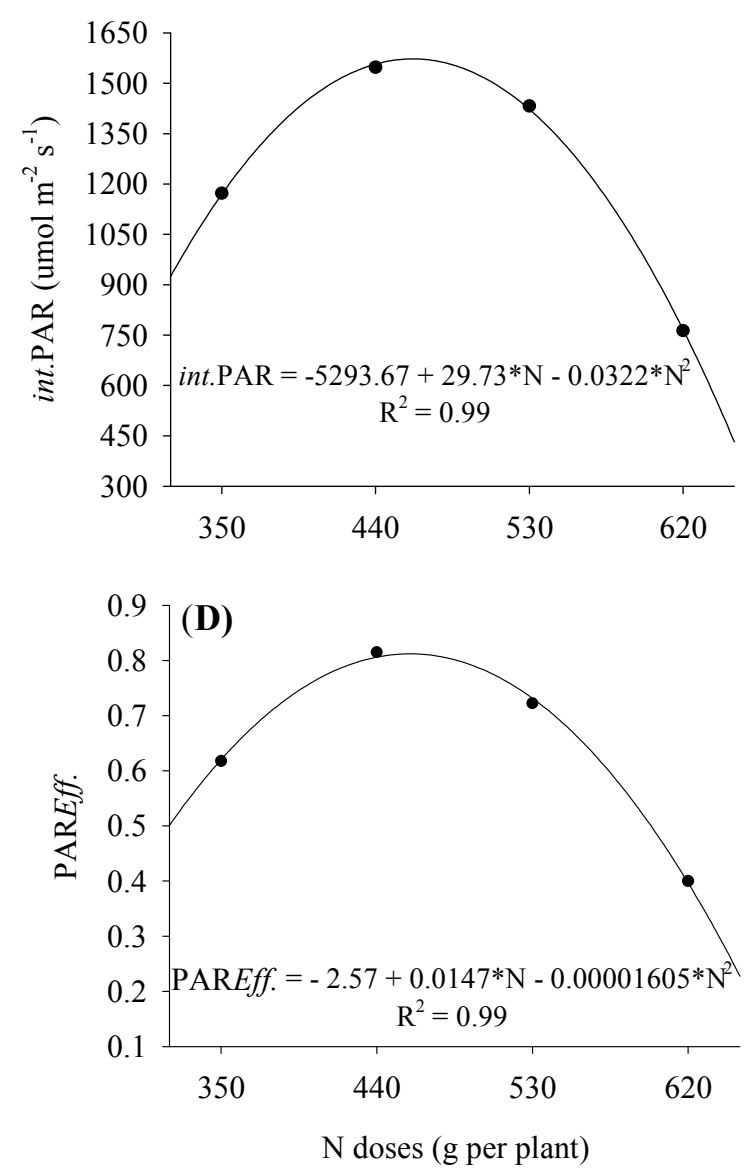

Figure 3. Intercepted photosynthetically active radiation (A and B) and use efficiency of photosynthetically active radiation $(\mathrm{C}$ and $\mathrm{D})$ of 'Formosa' papaya cultivated under different doses of coted and conventional urea.

Rev. Caatinga, Mossoró, v. 29, n. 3, p. 559 - 568, jul. - set., 2016 
Nitrogen essentiality to achieve high photosynthetic rates in papaya is evidenced by the positive relationship between these characteristics. Both int.PAR and PAREff. was incremented as $\mathrm{N}$ doses applied in the soil increased, which could be explained due to the high 'Formosa' papaya demand for this nutrient (OLIVEIRA; CALDAS, 2004), associated with the application of optimal doses since the organic matter content, the main source of $\mathrm{N}$ in the soil, presented low values before the experiment installation, as shown in Figure 1, favoring the effect of nitrogen fertilization. These results corroborate those observed by Taiz and Zeiger (2009), who observed that the plant photosynthetic capacity is dependent on nitrogen supply since a considerable fraction of this element is found in the leaves, allocated in proteins involved in the photosynthetic process. These authors also suggest that photosynthesis depends on several nitrogenous compounds such as enzymes and photosynthetic pigments for the production of carbon compounds that compose the aerial part. For this reason, plants photosynthetic ability and nitrogen metabolism are directly interconnected.

In addition, it is pertinent to highlight the high light saturation point of the crop fertilized with coated urea, which was above of $1,350 \mu \mathrm{mol} \mathrm{m} \mathrm{m}^{-2} \mathrm{~s}^{-1}$ (Figure $3 \mathrm{~A}$ ), allowing to find that there was no harmful light saturation to the crop since the maximum PAR registered above the canopy was $1,900 \mu \mathrm{mol} \mathrm{m} \mathrm{m}^{-1}$.

Martelleto et al. (2008) also observed the increase of the photosynthetically active radiation with the increasing $\mathrm{N}$ doses in 'Baixinho de Santa Amália' papaya when assessing the plants growth in protected environments with maximum radiation estimated in about $1,600 \mu \mathrm{mol} \mathrm{m} \mathrm{m}^{-2} \mathrm{~s}^{-1}$. Similarly, Cruz et al. (2007) found positive effects of nitrogen doses on photosynthetic active radiation in Golden papaya.

It is observed that the maximum dose of conventional urea estimated provided better results for int.PAR and PAREff. However, both stem diameter and plant height were enhanced with the application of urea coated with polymers when compared to the conventional urea. It is reported that the assessment period of physiological and phytotechnical parameters occurred at different physiological stages, at 120 and 275 days after planting, respectively, which contradicts the relationship between these attributes. Therefore, at four months old, the plants were still in full vegetative growth and because the conventional urea presents a rapid $\mathrm{N}$ release in the soil (CIVARDI et al., 2011), it probably favored a greater crop development at this stage, contributing to greater PAR interception efficiency.

For the average yield, registered during 120 days of harvest, it is observed that for both $\mathrm{N}$ sources there was a quadratic increase in yield as nitrogen doses increased in the soil, with superiority for the gradual release fertilizer (Figure 4A and B). Yield presented estimated maximum values of 14.30 and $8.70 \mathrm{t} \mathrm{ha}^{-1}$ with the doses of 498 and $460 \mathrm{~g}$ per plant for coated (Figure 4A) and conventional (Figure 4B) urea, respectively, with a reduction in yield with the increasing $\mathrm{N}$ doses in the soil from the maximum doses estimated for both sources.

The estimated maximum $\mathrm{N}$ doses were $498 \mathrm{~g}$ per plant for coated urea and $460 \mathrm{~g}$ per plant for conventional urea. Thus, in higher yields, the $\mathrm{N}$ dose in the polymerized urea source was $7.6 \%$ higher in relation to the conventional urea dose. On the other hand, with the application of coated urea, there was an increase of $39.2 \%$ in the maximum papaya yield. Thus, the application of $1.0 \mathrm{~g}$ of coated $\mathrm{N}$ promoted the production of $2.87 \mathrm{~g}$ of fruit per hectare, whereas $1.0 \mathrm{~g}$ of conventional $\mathrm{N}$ produced only $1.89 \mathrm{~g}$ of fruit per hectare. This outcome shows that polymerized $\mathrm{N}$ promoted a greater use efficiency of the $\mathrm{N}$ applied in the soil, seen by the production gain per unit of nutrient applied, as in Fageria (1998).
Coated urea

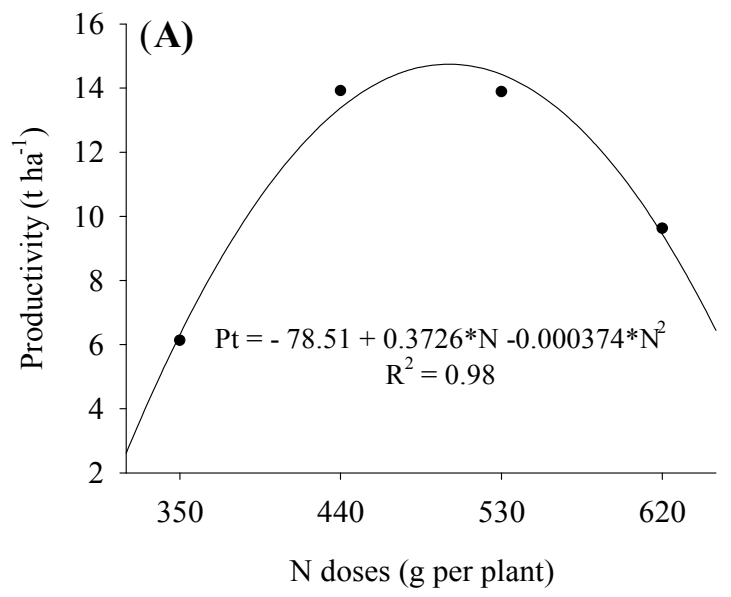

Conventional urea

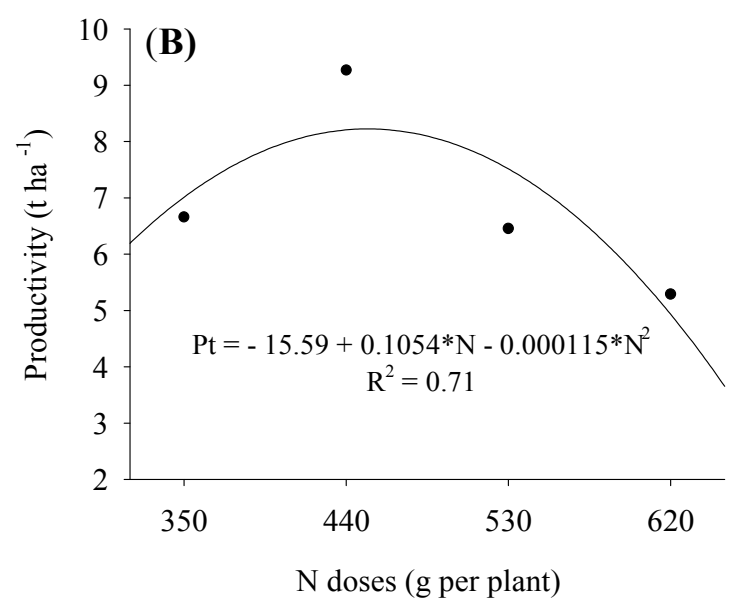

Figure 4. Yield of 'Formosa' papaya cultivated under different doses of coated and conventional urea. 
The superiority of the coated urea is attributed to the fact that fertilizers coated with polymers reduce $\mathrm{N}$ losses by leaching and volatilization, showing greater efficiency in yield of some crops due to its granules structure (OSMAN et al., 2009). Thus, the gradual $\mathrm{N}$ supply with more homogeneous distribution in the soil at the production phase is very important for papaya crop, favoring the synchronization between $\mathrm{N}$ supply and the physiological plant demand, such as the flowers and fruits formation (BRITO NETO et al., 2011).

The average yield of 'Formosa' papaya, regardless $\mathrm{N}$ source, is lower compared to findings of Alves et al. (2012) in Catolé da Rocha, PB, Brazil; Tosta et al. (2012) in Mossoró, RN, Brazil; and Marinho et al. (2010) in Linhares, ES, Brazil. These authors achieved yields of 23.90, 51.42 and $48.54 \mathrm{t}$ $\mathrm{ha}^{-1}$ along 6 months up to 'Formosa' papaya harvest.

However, the maximum yield observed for coated fertilizer $\left(14.30 \mathrm{t} \mathrm{ha}^{-1}\right)$ was higher than reports of Santos et al. (2016) $\left(8.75 \mathrm{t} \mathrm{ha}^{-1}\right)$ and Brito Neto et al. (2011) (13.00 t ha ${ }^{-1}$ ). Oliveira and Caldas et al. (2004) observed a yield range from 9.87 to $27.41 \mathrm{t} \mathrm{ha}^{-1}$ in a study with 6-month papaya production as a function of nitrogen, phosphorus and potassium fertilization, in Cruz das Almas, BA, Brazil.

The low yields found in this study may be ascribed to short-term harvest method (120 days or four months), mainly associated with low relative air humidity (Figure 1B), which meets values obtained by Reis and Campostrini (2008) and Oliveira et al. (2004). These authors stated an average relative air humidity from 60 to $85 \%$ for papaya bloom stage; also highlighting that below this range, as observed in this study, high levels of floral abortion may occur.

\section{CONCLUSIONS}

The coated urea promotes higher growth and average yield for 'Formosa' papaya when compared to conventional urea.

The application of $1.0 \mathrm{~g}$ of coated $\mathrm{N}$ promotes a production of $2.87 \mathrm{~g}$ of fruit per hectare, whereas $1.0 \mathrm{~g}$ of $\mathrm{N}$ in conventional urea source produces only $1.89 \mathrm{~g}$ of fruit per hectare, showing that polymerized $\mathrm{N}$ source increases use efficiency of $\mathrm{N}$ applied in the soil.

\section{ACKNOWLEDGEMENT}

We are grateful to the Coordenação do Aperfeiçoamento do Pessoal do Ensino Superior CAPES (Coordination for the Improvement of Higher Education Personnel - CAPES) for granting the master's scholarship to the first author.
We also thank the Banco do Nordeste do Brasil - BNB (Bank of Northeastern Brazil - BNB) for the financial support for implementing this research project.

In addition, we want to acknowledge the Kimberlit Agrociencias for providing the tested material as coated urea (Kimcoat $\mathrm{N}^{\circledR}$ ) covered with polymers.

\section{REFERENCES}

ALVES, A. S. et al. Produtividade do mamoeiro Havaí submetido a dosagens e intervalos de aplicação de biofertilizante bovino. Engenharia Ambiental, Espírito Santo do Pinhal, v. 9, n. 1, p. 100-109, 2012.

BRITO NETO, J. F. et al. Produtividade e qualidade de frutos de mamoeiro 'Sunrise Solo' em função de doses de nitrogênio e boro. Semina: Ciências Agrárias, Londrina, v. 32, n. 1, p. 69-80, 2011.

CIVARDI, E. A. et al. Ureia de liberação lenta aplicada superficialmente e ureia comum incorporada ao solo no rendimento do milho. Pesquisa Agropecuária Tropical, Goiânia, v. 41, n. 1, p. 52-59, 2011.

COELHO FILHO, M. A.; COELHO, E. F.; CRUZ, J. L. Uso da transpiração máxima de mamoeiro para o manejo de irrigação por gotejamento em regiões úmidas e sub-úmidas. 1. ed. Cruz das Almas, BA: Embrapa Mandioca e Fruticultura Tropical, 2006. 30 p. (Documentos, 162)

COSTA, A. N.; COSTA, A. F. S. Nutrição e adubação. In: MARTINS, D. S.; COSTA, A. F. S. A cultura do mamoeiro: tecnologias de produção. (Ed.). Vitória, ES: Incaper, 2003. p. 201-227.

CRUZ, J. L. et al. Níveis de nitrogênio e a taxa fotossintética do mamoeiro "Golden". Ciência Rural, Santa Maria, v. 37, n. 1, p. 67-71, 2007.

EMAN, E. et al. Effect of urea-formaldehyde as a slow release nitrogen fertilizer on productivity of mango trees. Green Farming, Jodhpur, v. 2, n. 9, p. 592-595, 2009.

EMBRAPA. Sistema brasileiro de classificação de solos. 3.ed. Brasília, DF: Embrapa, 2013. 353 p.

FAGERIA, N. K. Otimização da eficiência nutricional na produção das culturas. Revista Brasileira de Engenharia Agrícola e Ambiental, Campina Grande, v. 2, n. 1, p. 6-16, 1998.

FAN, X. H.; LI, Y. C. Effects of slow $\square$ release fertilizers on tomato growth and nitrogen leaching. 
Communications in Soil Science and Plant Analysis, Philadelphia, v. 40, n. 22, p. 3452-3468, 2009.

GRANT, C. A. et al. Crop yield and nitrogen concentration with controlled release urea and split applications of nitrogen as compared to non-coated urea applied at seeding. Field Crops Research, Amsterdam, v. 127, n. 1, p. 170-180, 2012.

INSTITUTO BRASILEIRO DE GEOGRAFIA E ESTATÍSTICA. Produção Agrícola 2012. Disponível em: <http://www.ibge.gov.br/home/ estatistica/economia/Publicacao__ completa.pdf $>$. Acesso em: 20 mai. 2013.

KANDIL, E. A.; FAWZI, M. I. F. M.; SHAHIN, F. $M$. The effect of some slow release nitrogen fertilizers on growth, nutrient status and fruiting of "Mit Ghamr" peach trees. Journal of American Science, New York, v. 6, n. 12, p. 195-201, 2010.

MARIN, S. L. D. Mamão papaya: produção, póscolheita e mercado. 1. ed. Fortaleza, CE: Instituto Frutal, 2004. 82 p.

MARINHO, A. B. et al. Produtividade e qualidade do fruto do mamoeiro híbrido UENF/ Caliman 01 sob diferentes lâminas de irrigação e doses de potássio. Agropecuária Técnica, Areia, v. 31, n. 2, p. 22-28, 2010.

MARTElleto, L. A. P. et al. Cultivo orgânico do mamoeiro "Baixinho de Santa Amália" em diferentes ambientes de proteção. Revista Brasileira de Fruticultura, Jaboticabal, v. 30, n. 3, p. 662-666, 2008.

NOELLSCH, A. J. et al. Corn response to conventional and slow- release nitrogen fertilizers across a clayppan landscape. Agronomy Journal, Madison, v. 101, n. 1, p. 1-14, 2009.

OLIVEIRA, A. M. G. et al. A cultura do mamoeiro. Cruz das Almas, BA: Embrapa/CNPMF, 1995. 55 p. (Circular Técnica, 21).

OLIVEIRA, A. M. G.; CALDAS, R. C. Produção do mamoeiro em função de adubação com nitrogênio, fósforo e potássio. Revista Brasileira de Fruticultura, Jaboticabal, v. 26, n. 1, p. 160-163, 2004.

OSMAN, S. M.; EL-RAHMAN, A. E. M. Effect of slow release nitrogen fertilization on growth and fruiting of guava under Mid Sinai conditions. Australian Journal of Basic and Applied Sciences, Punjab, v. 3, n. 4, p. 4366-4375, 2009.

RAIJ, B. V. et al. Análise química do solo para fins de fertilidade. 1. ed. Campinas, SP: Fundação Cargill, 1987. 170 p.

REIS, F. O.; CAMPOSTRINI, E. Trocas gasosas e eficiência fotoquímica potencial em mamoeiro do grupo 'Formosa' cultivado em condição de campo. Bragantia, Campinas, v. 67, n. 4, p. 815-822, 2008.

RESENDE, G. M.; COSTA, N. D. Características produtivas da melancia em diferentes espaçamentos de plantio. Horticultura Brasileira, Brasília, v. 21, n. 4, p. 695-698, 2003.

RODRIGUES, M. A. et al. Slow-release N fertilizers are not an alternative to urea for fertilization of autumn-grown tall cabbage. European Journal of Agronomy, Montpellier, v. 32, n. 2, p. 137-143, 2010 .

SANTOS, E. M. et al. Planting spacing and NK fertilizing on physiological indexes and fruit production of papaya under semiarid climate. Bragantia, Campinas, v. 75, n. 1, p. 63-69, 2016.

SANTOS, E. M. et al. Estado nutricional do mamoeiro Formosa (cv. Caliman 01) em função de adubação com NK e espaçamento de plantio. Comunicata Scientiae, Bom Jesus, v. 5, n. 3, p. 229 $-240,2014$.

SOUZA, E. A. et al. Crescimento e produtividade do mamoeiro fertirrigado com fósforo por gotejamento superficial e subsuperficial. Revista Brasileira de Fruticultura, Jaboticabal, v. 27, n. 3, p. 495-499, 2005.

SOUZA, T. V. et al. Crescimento e produtividade do mamoeiro fertirrigado com diferentes combinações de fontes nitrogenadas. Irriga, Botucatu, v. 12, n. 4 , p. 563-574, 2007.

TAIZ, L.; ZEIGER, E. Fisiologia Vegetal. 4. ed. São Paulo, SP: Artmed, 2009. 848 p.

TOSTA, M. S. et al. Mamoeiro Formosa sob doses de enxofre em Baraúnas-RN. Revista Verde de Agricultura e Desenvolvimento Sustentável, Mossoró, v. 7, n. 1, p. 122-128, 2012.

VARLET-GRANCHER, C. et al. Mise au point: rayonnement solaire absorbé ou intercepte par uncouvert vegétal. Agronomie, Paris, v. 9, n. 5, p. 419-439, 1989. 